\title{
BMJ Open Are family, neighbourhood and school social capital associated with higher self- rated health among Croatian high school students? A population-based study
}

\author{
Dario Novak, ${ }^{1,2}$ Etsuji Suzuki, ${ }^{3}$ Ichiro Kawachi ${ }^{4}$
}

To cite: Novak D, Suzuki E, Kawachi I. Are family, neighbourhood and school social capital associated with higher self-rated health among Croatian high school students? A population-based study. BMJ Open 2015;5: e007184. doi:10.1136/ bmjopen-2014-007184

- Prepublication history for this paper is available online. To view these files please visit the journal online (http://dx.doi.org/10.1136/ bmjopen-2014-007184).

Received 13 November 2014 Revised 30 April 2015 Accepted 7 May 2015

CrossMark

For numbered affiliations see end of article.

Correspondence to Dr Dario Novak; dario.novak@kif.hr

\section{ABSTRACT}

Objectives: We investigated the associations between self-rated health and social capital among Croatian high school students.

Design: A cross-sectional survey among high school students was carried out in the 2013-2014 school year. Setting: High schools in Croatia.

Participants: Subjects were 3427 high school students (1688 males and 1739 females), aged 17-18 years.

Main outcome measure: Self-rated health was assessed by the single item: "How do you perceive your health?". Possible responses were arranged along a fiveitem Likert-type scale: 1 very poor, 2 poor, 3 fair, 4 good, 5 excellent. The outcome was binarised as 'good health' (excellent, good or fair) versus 'poor health' (poor or very poor).

Methods: We calculated ORs and 95\% Cls for good self-rated health associated with family, neighbourhood and school social capital, while adjusting for gender, selfperceived socioeconomic status, psychological distress, physical activity and body mass index. We used generalised estimating equations using an exchangeable correlation matrix with robust SEs.

Results: Good self-rated health was significantly associated with higher family social capital (OR 2.43; $95 \% \mathrm{Cl} 1.55$ to 3.80 ), higher neighbourhood trust (OR 2.02; $95 \% \mathrm{Cl} 1.48$ to 2.76 ) and higher norms of reciprocity at school (OR 1.79; $95 \% \mathrm{Cl} 1.13$ to 2.84 ). When all of the social capital variables were entered simultaneously, good self-rated health remained significantly associated with higher family social capital (OR 1.98; $95 \% \mathrm{Cl} 1.19$ to 3.30), neighbourhood trust (OR $1.77 ; 95 \% \mathrm{Cl} 1.25$ to 2.51 ) and reciprocity at school (OR $1.71 ; 95 \%$ Cl 1.08 to 2.73 ).

Conclusions: Higher levels of social capital were independently associated with higher self-rated health among youth. Intervention and policies that leverage community social capital might serve as an avenue for health promotion in youth.

\section{INTRODUCTION}

Social capital has been defined as the "resources embedded in a social structure

\section{Strengths and limitations of this study}

- This study is one of the fewer studies to date that have focused on social capital and health among children and youth.

- We used a random sampling approach to select 20 high schools in Zagreb, all of which agreed to take part in the survey. A total of 3427 students $(93.8 \%)$ responded to the survey which was given during class.

- To clarify which source of social capital is likely to affect adolescents' health, we assessed three different sources of social capital-in the family, in the neighbourhood, and at school-among high school students.

- We used the generalised estimating equations using an exchangeable correlation matrix with robust SEs in order to correct SEs for clustering.

- Owing to the cross-sectional design, we cannot exclude the possibility of reverse causation. Since we used a subjective measure of health and social capital, there is a possibility of common method bias.

which are accessed and/or mobilised in purposive actions." ${ }^{2}$ Some scholars have conceptualised social capital as the social networks themselves, or as both the network structures and the resources channelled through the networks. ${ }^{3}{ }^{4}$ Social capital has garnered increasing attention as a potential influence on the development of youth. In the field of education, research has primarily focused on the role of social capital in children's academic performance; ${ }^{5} 6$ however, subsequent research has expanded the range of outcomes to include health behaviours and population health outcomes. ${ }^{4} 7$ Social capital theory posits that interpersonal trust, norms of reciprocity and exchange of social support between members of a networks each constitutes a type of resource, and that access to these resources may facilitate the actions of group members. ${ }^{48}$ Investigation 
of possible influences of social capital on health may be particularly salient in adolescents because previous work has suggested that contextual influences may have effects on the somatic and psychological development of young people throughout the life course. ${ }^{9} 10$

Associations between social capital and health have been extensively investigated in adult samples. ${ }^{11-13}$ Social capital has been found in previous studies to be related to physical activity and body mass index (BMI). ${ }^{14-16}$ At the same time, physical activity and BMI are predictors of self-rated health. Therefore, both are not considered to be confounders of the relation between social capital and self-rated health. Rather, our underlying hypothesised model is: social capital $\rightarrow$ physical activity/BMI $\rightarrow$ self-rated health. However, fewer studies to date have focused on social capital and health among children and youth. According to Urie Bronfenbrenner's ecological systems theory of child development, human development is conceptualised as being shaped by the interaction between an individual and his or her environment; furthermore, there are many different levels of environmental influences that can affect a child's development, starting with people and institutions immediately surrounding the child (ie, parents and families), to school environments, to residential neighbourhoods and eventually the societal culture. ${ }^{17}$ In-line with this, we hypothesised that family, neighbourhood and school social capital may be associated with an adolescent's good health and that students who report higher levels of social capital in all three domains will have higher self-rated health. However, few studies have simultaneously examined the contribution of different sources of social capital to youth health.

Accordingly, in the present study, we investigated the influences of different sources of social capital-in the family, in the neighbourhood, and at school-on levels of self-rated health among a sample of high school students in Croatia.

\section{METHODS}

\section{Participants}

We administered a survey among high school students in Zagreb, a mid-sized urban city in central Croatia with a population of about 1000000 people. A random sampling approach was used to select high schools. All of the 20 schools that we approached agreed to take part in the survey, representing 3650 students enrolled in the 2013-2014 school year. Of these, 3427 students (1688 males and 1739 females, aged 17-18 years) responded to the survey $(93.8 \%)$ which was given during class. Finally, the data of 3427 students aged 17-18 years were analysed.

\section{Self-rated health}

Self-rated health was assessed in these young adolescents using the standard single-item measure: "How do you perceive your health?". Possible responses were arranged along a five-item Likert-type scale: 1 very poor, 2 poor,
3 fair, 4 good, 5 excellent. We binarised the outcome, that is, fair, good and excellent were collapsed into one category (good health), while poor and very poor were designated as poor health. Perceived health is an easily administered and widely used outcome measure in social epidemiology studies, and it has been shown to be a reliable predictor of mortality and healthcare use in adults. ${ }^{18-20}$ The measure has also been used in adolescents. ${ }^{21-24}$

\section{Social capital indicators}

On the survey, we inquired about individual perceptions of social capital in the family, neighbourhood and high school settings. ${ }^{3} 725$ Family social capital was assessed by the question: "Do you feel your family understands and gives attention to you?". ${ }^{26}$ Neighbourhood social capital was assessed by using two items; "Do you feel people trust each other in your neighbourhood (neighbourhood trust)?" "Do you feel that your neighbours step in to criticise someone's deviant behaviour during high school (informal social control)?". ${ }^{7}$ School social capital was assessed by three items; "Do you feel teachers and students trust each other in your high school (vertical school trust)?" "Do you feel students trust each other in your high school (horizontal school trust)?" "Do you feel students collaborate with each other in your high school (reciprocity at school)?" The response options were: 'strongly agree'; 'agree'; 'neither agree or disagree'; 'disagree'; 'strongly disagree'. Then, for each response, we created a dichotomous variable (high: 'strongly agree', 'agree' and 'neither agree or disagree'; low: 'disagree' and 'strongly disagree'). ${ }^{7}$ The Cronbach $\alpha$ of the school social capital scale was 0.71 , and since other domains have fewer than three questions, we considered it not appropriate to check Cronbach $\alpha$ s for these scales.

\section{Covariates}

As a measure of physical activity, we considered students' total physical activity in the past 7 days. Physical activity was assessed using the validated short version of the International Physical Activity Questionnaire (IPAQ) and was expressed as metabolic equivalent-hours per week). ${ }^{27}$ As additional potential mediators, we considered BMI based on the calculation from self-reported height and weight (scoring of responses in the range $\geq 25 \mathrm{~kg} / \mathrm{m}^{2}$ vs $<25 \mathrm{~kg} / \mathrm{m}^{2}$ discriminates between respondents with and without high BMI). Socioeconomic status (SES) was entered in our regression models as a potential confounder, that is, theoretically associated with selfrated health and social capital. ${ }^{28}$ The classification of SES was based on both parents' occupation at the time when the research was conducted. Self-perceived SES was categorised into three levels as high SES (ie, managers and professionals), middle SES (white collar) and low SES (blue collar), ${ }^{29}$ and it was dichotomised as high/middle (responses in the range 2-4) and low (responses in the range 5-6). Psychological distress was also assessed as a potential confounder using the 
six-item Kessler scale by the questions: "About how often during the past 30 days did you feel nervous?", "During the past 30 days, about how often did you feel hopeless?", "During the past 30 days, about how often did you feel restless or fidgety?", "How often did you feel so depressed that nothing could cheer you up?", "During the past 30 days, about how often did you feel that everything was an effort?" and "During the past 30 days, about how often did you feel worthless?". ${ }^{30}$ Each question is scored from 0 (none of the time) to 4 (all of the time). Scores of the six questions were then summed (0-24), with a lower score indicating low levels of psychological distress. Previous research has shown that dichotomous scoring of responses in the range 13+ versus 0-12 discriminates between respondents with and without significant psychological distress. ${ }^{30} 31$ A test of interaction between psychological distress and gender is performed and there is statistical gender difference in psychological distress $(\mathrm{p}<0.001)$.

\section{Data analysis}

We used the generalised estimating equations using an exchangeable correlation matrix with robust SEs in order to correct SEs for clustering. We calculated ORs and $95 \%$ CIs for good self-rated health according to levels of perceived social capital. The association of selfrated health with social capital indicators was examined by conducting a multiple logistic regression analysis. Furthermore, the study included students from 20 schools; thus, one of the assumptions was that the measurements within school might not be independent. Therefore, the cluster effect was considered in the analysis. For this purpose, we adjusted the SEs by computing clustered robust SEs for the coefficients. We also performed a $\chi^{2}$ test to check the statistical significance of the gender difference in proportion of boys versus girls reporting good self-rated health. As potential confounders, we entered gender, self-perceived SES and psychological distress. We also included physical activity and BMI as potential mediators of the association between social capital and self-rated health. We investigated the association between self-rated health and family social capital (model 1), neighbourhood social capital (model 2 ) and school social capital (model 3). Finally, we entered all of these social capital variables simultaneously (model 4) to assess their independent contributions to self-rated health. The interaction term between social capital and gender was not statistically significant so we dropped the sex-stratified analyses. A p value of $<0.05$ (two sided) was considered statistically significant. All statistical analyses were performed with Stata, V.12 (StataCorp, Texas, USA).

\section{RESULTS}

Boys reported a higher percentage of good self-rated health $(85.8 \%)$ compared with girls $(75.6 \%)$. Roughly $20 \%$ of the participants reported poor health. It is worth noting that the prevalence of psychological distress in girls was twice as high as that in boys. Males do generally have a higher BMI than females $\left(22.95 \pm 2.85 \mathrm{~kg} / \mathrm{m}^{2}\right.$ vs $\left.20.81 \pm 2.54 \mathrm{~kg} / \mathrm{m}^{2}\right)$. Most adolescents evaluated their family SES as high/middle $(60.2 \%)$ with no statistically significant differences between boys and girls. Boys are significantly more physically active than girls. It is worthwhile to note that a $\chi^{2}$ test shows the statistical significance of the gender difference in proportion of boys versus girls reporting good self-rated health (table 1).

The association between social capital and self-rated health is shown in table 2. Overall, self-rated health was significantly associated with each domain of social capital. Good self-rated health was significantly associated with higher family social capital (OR 2.43; 95\% CI 1.55 to 3.80) and higher neighbourhood trust (OR 2.02; $95 \%$ CI 1.48 to 2.76). Regarding school social capital, good self-rated health was significantly associated only with perceptions of reciprocity at school (OR 1.79; $95 \%$ CI 1.13 to 2.84 ). When all social capital variables were entered into the model (model 4), good self-rated health was significantly associated with higher family social capital (OR 1.98; 95\% CI 1.19 to 3.30), neighbourhood trust (OR 1.77; 95\% CI 1.25 to 2.51 ) and reciprocity at school (OR $1.71 ; 95 \%$ CI 1.08 to 2.73 ).

Table 3 presents the association between family, neighbourhood and school social capital with good self-rated health among high school students. Good self-rated health was significantly associated with higher family social capital (coefficient $0.88 ; 95 \%$ CI 0.35 to 1.42 ), higher neighbourhood trust (coefficient $0.70 ; 95 \%$ CI 0.34 to 1.06 ) and higher norms of reciprocity at school (coefficient 0.58 ; $95 \%$ CI 0.13 to 1.04 ). When all types of social capital were entered simultaneously, good selfrated health remained significantly associated with higher family social capital (coefficient 0.68; 95\% CI 0.13 to 1.23 ), neighbourhood trust (coefficient 0.57; $95 \%$ CI 0.20 to 0.94 ) and reciprocity at school (coefficient $0.54 ; 95 \%$ CI 0.08 to 0.99 ).

\section{DISCUSSION}

Previous studies in the USA and Europe have suggested that higher levels of informal social control were associated with higher levels of perceived health. ${ }^{10}$ Drukker $e t a \hat{l}^{32}$ found that higher levels of community informal social control in the Netherlands may directly prevent young people from engaging in deleterious health behaviours as well as indirectly provide them with selfconfidence and a sense of protection. Furuta $e t a l^{7}$ have shown that the association of social capital with self-rated oral health is not uniform; higher trust is associated with better oral health, whereas higher informal control in the community is associated with worse oral health.

To better understand the findings of this research, it is very important to briefly explain the Croatian social context and the theoretical approach to young people. The mid-1980s in Croatia was a period of socialism 
Table 1 Characteristics of the study subjects, Zagreb, Croatia, 2014

\begin{tabular}{|c|c|c|c|c|}
\hline & $\begin{array}{l}\text { Total } \\
(\mathrm{N}=3427) \\
\mathrm{N}(\%)\end{array}$ & $\begin{array}{l}\text { Males } \\
(\mathrm{N}=1688) \\
\mathrm{N}(\%)\end{array}$ & $\begin{array}{l}\text { Females } \\
(\mathrm{N}=1739) \\
\mathrm{N}(\%)\end{array}$ & p Value* \\
\hline \multicolumn{5}{|l|}{ Self-rated health } \\
\hline Poor & 664 (19.4) & 239 (14.2) & 425 (24.4) & \\
\hline Good & 2763 (80.6) & 1449 (85.8) & $1314(75.6)$ & $<0.001$ \\
\hline \multicolumn{5}{|l|}{ Family social capital } \\
\hline Low & $185(5.4)$ & $90(5.4)$ & $95(5.5)$ & \\
\hline High & 3242 (94.6) & 1598 (94.6) & $1644(94.5)$ & 0.808 \\
\hline \multicolumn{5}{|l|}{ Neighbourhood trust } \\
\hline Low & 1104 (32.2) & $466(27.6)$ & $638(36.6)$ & \\
\hline High & $2323(67.8)$ & $1222(72.4)$ & $1101(63.4)$ & $<0.001$ \\
\hline \multicolumn{5}{|l|}{ Informal social control } \\
\hline Low & $828(24.2)$ & $419(24.8)$ & 409 (23.5) & \\
\hline High & 2599 (75.8) & 1269 (75.2) & $1330(76.5)$ & 0.342 \\
\hline \multicolumn{5}{|l|}{ Vertical school trust } \\
\hline Low & 1050 (30.6) & 485 (28.7) & 565 (32.5) & \\
\hline High & 2377 (69.4) & $1203(71.2)$ & $1174(67.5)$ & 0.014 \\
\hline \multicolumn{5}{|c|}{ Horizontal school trust } \\
\hline Low & $840(24.5)$ & 339 (20.1) & $501(28.8)$ & \\
\hline High & $2587(75.5)$ & 1349 (79.9) & $1238(71.2)$ & $<0.001$ \\
\hline \multicolumn{5}{|l|}{ Reciprocity at school } \\
\hline Low & 459 (13.4) & $186(11.1)$ & $273(15.7)$ & \\
\hline High & 2968 (86.6) & $1502(88.9)$ & $1466(84.3)$ & $<0.001$ \\
\hline \multicolumn{5}{|l|}{ Body mass index } \\
\hline Normal & 3001 (87.6) & 1367 (80.9) & 1634 (93.9) & \\
\hline Overweight/obese & 426 (12.4) & $321(19.1)$ & $105(6.1)$ & $<0.001$ \\
\hline \multicolumn{5}{|c|}{ Self-perceived socioeconomic status } \\
\hline High/middle & $2064(60.2)$ & $1008(59.7)$ & $1056(60.7)$ & \\
\hline Low & $1363(39.8)$ & $680(40.3)$ & $683(39.3)$ & 0.706 \\
\hline \multicolumn{5}{|l|}{ Psychological distress } \\
\hline High & $848(24.7)$ & $274(16.3)$ & $574(33.0)$ & \\
\hline Low & 2579 (75.3) & $1414(83.7)$ & $1165(67.0)$ & $<0.001$ \\
\hline \multicolumn{5}{|l|}{ Physical activity } \\
\hline High/moderate & 2943 (85.9) & 1499 (88.8) & $1444(83.1)$ & \\
\hline Low & $484(14.1)$ & $189(11.2)$ & 295 (16.9) & $<0.001$ \\
\hline
\end{tabular}

before the collapse of the Soviet bloc. The first decade of the 1990s was more turbulent in Croatia compared with other post socialist countries. Croatia experienced armed conflicts that lasted for several years. Finally, at the beginning of the 1990s with the state's declaration of independence, and the abolition of the totalitarian regime, the nation became one of many transition countries. Young people in Croatia are one of the population segments most rapidly affected by these processes and changes. The reasons for this are multiple and related to the timing of political transition, with the transition from childhood to adulthood. ${ }^{33}$

In this study, we have found a statistically significant association between higher levels of family social capital and higher self-rated health. For young people, family should be important for 'being there' in times of need and family members are often regarded as a crucial source of support. ${ }^{34}$ Morgan and Haglund ${ }^{35}$ reported that a sense of belonging in family was related to selfrated health and health behaviours in adolescents.
In transitional societies, the changes in hierarchical order and value structures accompanying the shift from socialism to free markets meant that families became especially important as a source of social support. ${ }^{36}$

We also found that those living in high-trust communities reported better health compared with youth living in low-trust communities. According to surveys, Croatian youth frequently spend their time with friends in the neighbourhood engaged in sport or other activities (ie, watching TV and videos, listening to the radio). ${ }^{33}$

The indicators based in the school social environment suggested that higher reciprocity at school (collaboration between pupils) was associated with higher selfrated health, whereas vertical and horizontal social capital were not significantly associated with self-rated health. Spending time with peers at school may engender a sense of belonging, ${ }^{34}$ and it may promote better health. The data show that $78 \%$ of Croatian youth frequently talk to their school peers about going out and leisure, music, movies and books. ${ }^{33}$ A previous study in 
Table 2 ORs for good self-rated health among high school students, Zagreb, Croatia, 2014

\begin{tabular}{|c|c|c|c|c|}
\hline & $\begin{array}{l}\text { Model } 1 \\
\text { OR }(95 \% \mathrm{Cl})\end{array}$ & $\begin{array}{l}\text { Model } 2 \\
\text { OR }(95 \% \mathrm{Cl})\end{array}$ & $\begin{array}{l}\text { Model } 3 \\
\text { OR }(95 \% \mathrm{CI})\end{array}$ & $\begin{array}{l}\text { Model } 4 \\
\text { OR }(95 \% \mathrm{Cl})\end{array}$ \\
\hline \multicolumn{5}{|l|}{ Family social capital } \\
\hline High & $2.43(1.55 \text { to } 3.80)^{\star \star \star}$ & & & $1.98(1.19 \text { to } 3.30)^{\star \star}$ \\
\hline \multicolumn{5}{|l|}{ Neighbourhood trust } \\
\hline High & & $2.02(1.48 \text { to } 2.76)^{\star \star \star}$ & & $1.77(1.25 \text { to } 2.51)^{\star \star \star}$ \\
\hline \multicolumn{5}{|l|}{ Informal social control } \\
\hline $\begin{array}{l}\text { Low } \\
\text { High }\end{array}$ & & 1.42 (0.99 to 2.04$)$ & & $1.37(0.95$ to 1.98$)$ \\
\hline \multicolumn{5}{|l|}{ Vertical school trust } \\
\hline High & & & 1.34 (0.99 to 1.81$)$ & 1.19 (0.87 to 1.62$)$ \\
\hline \multicolumn{5}{|l|}{ Horizontal school trust } \\
\hline High & & & 1.24 (0.83 to 1.84$)$ & $1.19(0.79$ to 1.79$)$ \\
\hline \multicolumn{5}{|l|}{ Reciprocity at school } \\
\hline High & & & $1.79(1.13 \text { to } 2.84)^{\star \star}$ & $1.71(1.08 \text { to } 2.73)^{*}$ \\
\hline \multicolumn{4}{|l|}{ Gender } & Male \\
\hline Female & $0.46(0.29 \text { to } 0.73)^{\star \star \star}$ & $0.49(0.31 \text { to } 0.78)^{\star \star}$ & $0.48(0.30 \text { to } 0.78)^{\star \star}$ & $0.48(0.30 \text { to } 0.79)^{\star *}$ \\
\hline \multicolumn{5}{|l|}{ Normal } \\
\hline Overweight/obese & $0.44(0.25 \text { to } 0.77)^{\star \star}$ & $0.43(0.23 \text { to } 0.78)^{\star \star}$ & $0.43(0.23 \text { to } 0.79)^{\star \star}$ & $0.42(0.23 \text { to } 0.77)^{\star \star}$ \\
\hline \multicolumn{5}{|c|}{$\begin{array}{l}\text { Self-perceived socioeconomic status } \\
\text { High/middle }\end{array}$} \\
\hline Low & $1.01(0.64$ to 1.60$)$ & 1.05 (0.66 to 1.68$)$ & 1.03 (0.65 to 1.64$)$ & $1.05(0.66$ to 1.65$)$ \\
\hline \multicolumn{5}{|l|}{ Psychological distress } \\
\hline Low & $0.37(0.24 \text { to } 0.57)^{\star \star \star}$ & $0.38(0.24 \text { to } 0.59)^{\star \star *}$ & $0.38(0.24 \text { to } 0.59)^{\star \star *}$ & $0.41(0.26 \text { to } 0.64)^{\star \star \star}$ \\
\hline $\begin{array}{l}\text { Physical activity } \\
\text { High/moderate }\end{array}$ & \multicolumn{4}{|c|}{ Physical activity } \\
\hline Low & $0.64(0.42 \text { to } 1.00)^{*}$ & $0.65(0.42 \text { to } 1.01)^{*}$ & $0.65(0.41 \text { to } 1.01)^{*}$ & $0.66(0.42 \text { to } 1.04)^{\star}$ \\
\hline \multicolumn{5}{|c|}{$\begin{array}{l}\text { These four models were examined in a sequence of four logistic regression models considering clustering for schools. } \\
\text { Model 1: examine the association between family social capital and youth self-rated health adjusting for gender, body mass index, } \\
\text { self-perceived socioeconomic status, psychological distress and physical activity. } \\
\text { Model 2: examine the association between neighbourhood social capital and youth self-rated health adjusting for gender, body mass index, } \\
\text { self-perceived socioeconomic status, psychological distress and physical activity. } \\
\text { Model 3: examine the association between school social capital and youth self-rated health adjusting for gender, body mass index, } \\
\text { self-perceived socioeconomic status, psychological distress and physical activity. } \\
\text { Model 4: examine the association between all social capital variables and youth self-rated health adjusting for gender, body mass index, } \\
\text { self-perceived socioeconomic status, psychological distress and physical activity. } \\
{ }^{*} p<0.05,{ }^{* \star} p<0.01,{ }^{* \star *} p<0.001 \text {. }\end{array}$} \\
\hline
\end{tabular}

Denmark found that school connectedness and a sense of belonging may have a strong impact on adolescent psychological health. ${ }^{37}$

Our study has some limitations. First, owing to the cross-sectional design, we cannot exclude the possibility of reverse causation, that is, poor health led to a low level of trust and other indicators of social capital. To mitigate this, we adjusted for psychological distress. In other words, the students with psychological distress would report lower levels of social capital in all three domains simultaneously and psychological distress could potentially affect their self-ratings of health. Therefore, we adjusted for individual differences in psychological distress in order to rule out this possible bias. When we included an interaction term between psychological distress and gender, its coefficient was statistically significant. However, we observed no substantial change in the association between social capital indicators and good health. Moreover, the differential effect estimates of each type of social capital on health cannot be fully explained by reverse causation. Second, we used a subjective measure of health and social capital, and therefore there is a possibility of common method bias which may have resulted in bias away from the null. Again, the differential findings for each type of social capital suggest that this is less likely. Third, since the students responded to the questionnaires during the class, there is a possibility of measurement error of school social 
Table 3 Coefficients for good self-rated health associated with family, neighbourhood and school social capital among high school students, Zagreb, Croatia, 2014

\begin{tabular}{|c|c|c|c|c|}
\hline & $\begin{array}{l}\text { Model } 1 \\
\text { Coefficient }(95 \% \mathrm{Cl})\end{array}$ & $\begin{array}{l}\text { Model } 2 \\
\text { Coefficient }(95 \% \mathrm{CI})\end{array}$ & $\begin{array}{l}\text { Model } 3 \\
\text { Coefficient }(95 \% \mathrm{Cl})\end{array}$ & $\begin{array}{l}\text { Model } 4 \\
\text { Coefficient }(95 \% \mathrm{CI})\end{array}$ \\
\hline \multicolumn{5}{|c|}{ Family social capital } \\
\hline High & $0.88(0.35 \text { to } 1.42)^{\star \star \star}$ & & & $0.68(0.13 \text { to } 1.23)^{\star \star}$ \\
\hline \multicolumn{5}{|c|}{ Neighbourhood trust } \\
\hline \multicolumn{5}{|c|}{ Low } \\
\hline High & & $0.70(0.34 \text { to } 1.06)^{\star \star \star}$ & & $0.57(0.20 \text { to } 0.94)^{\star \star}$ \\
\hline \multicolumn{5}{|c|}{ Informal social control } \\
\hline \multicolumn{5}{|c|}{ Low } \\
\hline High & & $0.35(-0.03$ to 0.74$)$ & & $0.31(-0.07$ to 0.71$)$ \\
\hline \multicolumn{5}{|c|}{ Vertical school trust } \\
\hline \multicolumn{5}{|c|}{ Low } \\
\hline High & & & $0.29(-0.09$ to 0.69$)$ & $0.17(-0.22$ to 0.57$)$ \\
\hline \multicolumn{5}{|c|}{ Horizontal school trust } \\
\hline \multicolumn{5}{|c|}{ Low } \\
\hline High & & & $0.21(-0.21$ to 0.65$)$ & $0.17(-0.25$ to 0.61$)$ \\
\hline \multicolumn{5}{|c|}{ Reciprocity at school } \\
\hline \multicolumn{5}{|c|}{ Low } \\
\hline High & & & $0.58(0.13 \text { to } 1.04)^{\star \star}$ & $0.54(0.08 \text { to } 0.99)^{\star}$ \\
\hline \multicolumn{5}{|l|}{ Gender } \\
\hline Female & $-0.77(-1.18 \text { to }-0.36)^{\star \star *}$ & $-0.70(-1.11 \text { to }-0.29)^{\star \star *}$ & $-0.71(-1.12 \text { to }-0.30)^{\star \star \star}$ & $-0.71(-1.12 \text { to }-0.30)^{\star \star *}$ \\
\hline \multicolumn{5}{|c|}{ Body mass index } \\
\hline \multicolumn{5}{|c|}{ Normal } \\
\hline $\begin{array}{l}\text { Overweight/ } \\
\text { obese }\end{array}$ & $-0.81(-1.28 \text { to }-0.34)^{\star * *}$ & $-0.83(-1.30 \text { to }-0.36)^{\star \star \star}$ & $-0.83(-1.31 \text { to }-0.36)^{\star \star \star}$ & $-0.84(-1.32 \text { to }-0.36)^{\star \star \star}$ \\
\hline \multicolumn{5}{|c|}{ Self-perceived socioeconomic status } \\
\hline Low & $0.01(-0.35$ to 0.38$)$ & $0.05(-0.31$ to 0.42$)$ & $0.03(-0.33$ to 0.40$)$ & $0.04(-0.32$ to 0.42$)$ \\
\hline \multicolumn{5}{|c|}{$\begin{array}{l}\text { Psychological distress } \\
\text { High }\end{array}$} \\
\hline Low & $-0.97(-1.33 \text { to }-0.60)^{\star * *}$ & $-0.96(-0.32 \text { to }-0.59)^{\star * *}$ & $-0.95(-1.32 \text { to }-0.59)^{\star \star *}$ & $-0.87(-1.24 \text { to }-0.50)^{\star \star \star}$ \\
\hline \multicolumn{5}{|c|}{ 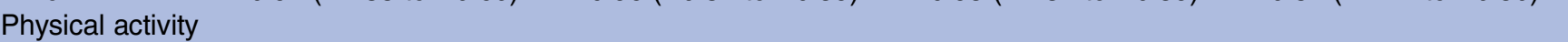 } \\
\hline Low & $-0.43(-0.87 \text { to } 0.00)^{\star}$ & $-0.42(-0.86 \text { to } 0.01)^{*}$ & $-0.42(-0.87 \text { to } 0.01)^{*}$ & $-0.40(-0.85$ to 0.35$)$ \\
\hline \multicolumn{5}{|c|}{$\begin{array}{l}\text { These four models were estimated by generalised estimating equations using an exchangeable correlation matrix with robust SEs. } \\
\text { Model 1: examine the association between family social capital and youth self-rated health adjusting for body mass index, self-perceived } \\
\text { socioeconomic status, psychological distress and physical activity. } \\
\text { Model 2: examine the association between neighbourhood social capital and youth self-rated health adjusting for body mass index, } \\
\text { self-perceived socioeconomic status, psychological distress and physical activity. } \\
\text { Model 3: examine the association between school social capital and youth self-rated health adjusting for body mass index, self-perceived } \\
\text { socioeconomic status, psychological distress and physical activity. } \\
\text { Model 4: examine the association between all social capital variables and youth self-rated health adjusting for body mass index, } \\
\text { self-perceived socioeconomic status, psychological distress and physical activity. }\end{array}$} \\
\hline
\end{tabular}

capital, in particular vertical social capital. Additionally, the possibility of type 1 error is high because of the clustering. We used the generalised estimating equations using an exchangeable correlation matrix with robust SEs in order to correct SEs for clustering. Fourth, the social capital variables in our study are analysed at the individual level. Therefore, we are referring to the students' individual perceptions of social capital. Unfortunately, we did not have information about which neighbourhoods the respondents lived in nor about which classrooms the students attended within each school. We cannot fully disentangle the effects of school social capital and neighbourhood social capital in this study, partly because of the lack of information about class and neighbourhood. And fifth, all types of social capital were assessed in the primary sample. Future studies are warranted to assess all three domains (family, neighbourhood and school social capital) by approaching different sample subjects who are not participating in the primary sample.

This study shows that higher levels of family social capital, neighbourhood trust and reciprocity school (ie, collaboration relationships between pupils) were associated with better health among youth. Interestingly, the interaction term between social capital and gender was not statistically significant in this study, although there 
are some researches showing that, among adolescents, girls tend to report higher levels of social capital, especially school and family belonging than do boys. ${ }^{38}$ We can speculate that this was found since adolescent girls have a greater number of friends than do boys; they expect and desire more nurturing behaviour from their friends and family members, and experience more empathy, more self-disclosure and less overt hostility in their friendships than do boys. ${ }^{39}$ Additional studies are needed to identify interventions that can increase social capital to engender healthy habits with the ultimate goal of achieving healthier students. More studies exploring social capital and health in different countries should be conducted since social capital in general and in particular levels of informal social control may depend on different cultural norms and values. ${ }^{40} 41$

\section{Author affiliations}

${ }^{1}$ Department of General and Applied Kinesiology, University of Zagreb Faculty of Kinesiology, Zagreb, Croatia

${ }^{2}$ Postdoctoral Fellow at Harvard University, Harvard T.H. Chan School of

Public Health, Takemi Program in International Health, Boston,

Massachusetts, USA

${ }^{3}$ Department of Epidemiology, Graduate School of Medicine, Dentistry and Pharmaceutical Sciences, Okayama University, Okayama, Japan

${ }^{4}$ Department of Social and Behavioral Sciences, Harvard T.H. Chan School of Public Health, Boston, Massachusetts, USA

\section{Twitter Follow Dario Novak at @DNovakPhD}

Acknowledgements The authors would like to thank the students and teachers for their enthusiastic participation in this study.

Contributors DN conceptualised and designed the study, conducted the statistical analyses and interpreted the data, and wrote the article. ES participated in the conceptualisation of the study, contributed to the drafting of the article and reviewed the paper. IK reviewed the results and contributed to the drafting of the article. All authors approved the final manuscript.

Funding This research was self-funded.

Competing interests None declared.

Patient consent Obtained.

Ethics approval Ethics Committee/Institutional Review Board of the Faculty of Kinesiology University of Zagreb, Croatia.

Provenance and peer review Not commissioned; externally peer reviewed.

Data sharing statement The authors confirm that all data underlying the findings are freely available.

Open Access This is an Open Access article distributed in accordance with the Creative Commons Attribution Non Commercial (CC BY-NC 4.0) license, which permits others to distribute, remix, adapt, build upon this work noncommercially, and license their derivative works on different terms, provided the original work is properly cited and the use is non-commercial. See: http:// creativecommons.org/licenses/by-nc/4.0/

\section{REFERENCES}

1. Lin N. Social capital: a theory of social structure and action. New York: Cambridge University Press, 2001:95-139.

2. Kim D, Subramanian SV, Kawachi I. Bonding versus bridging social capital and their associations with self rated health: a multilevel analysis of 40 US communities. J Epidemiol Community Health 2006;60:116-22.

3. Putnam RD. Bowling alone. New York: Simon \& Schuster, 2000:296.
4. Kawachi I, Subramanian SV, Kim D. Social capital and health. New York: Springer Science, 2010:215-28.

5. Coleman JS. Social capital and the development of youth. Momentum 1987;18:6-8.

6. Coleman JS. Foundations of social theory. London: The Belknap Press of Harvard University Press, 1990:300-2.

7. Furuta M, Ekuni D, Takao S, et al. Social capital and self-rated oral health among young people. Community Dent Oral Epidemiol 2012;40:97-104.

8. Putnam RD. Making democracy work: civic traditions in modern Italy. Princeton: Princeton University Press, 1993:167.

9. Kalff AC, Kroes M, Vles JS, et al. Neighbourhood level and individual level SES effects on child problem behaviour: a multilevel analysis. J Epidemiol Community Health 2001;55:246-50.

10. Drukker M, Buka SL, Kaplan C. Social capital and young adolescents' perceived health in different sociocultural settings. Soc Sci Med 2005;61:185-98.

11. Kim D, Subramanian SV, Kawachi I. Social capital and physical health: a systematic review of the literature. In: Kawachi I, Subramanian SV, Kim D, eds. Social capital and health. New York: Springer, 2008:139-90.

12. Murayama H, Fujiwara $\mathrm{Y}$, Kawachi I. Social capital and health: a review of prospective multilevel studies. J Epidemiol 2012;22:179-87.

13. Virtanen M, Ervasti M, Oksanen T, et al. Social capital in schools. In: Kawachi I, Takao S, Subramanian SV, eds. Global perspectives on social capital and health. New York: Springer, 2013:65-85.

14. Lindstrom M, Hanson BS, Ostergren PO. Socioeconomic differences in leisure-time physical activity: the role of social participation and social capital in sharping health related behavior. Soc Sci Med 2001;52:441-51.

15. Lindstrom M, Moghaddassi M, Merlo J. Social capital and leisure-time physical activity: a population-based multilevel analysis of individual and neighbourhood level data in Malmo. J Epidemiol Community Health 2003;57:23-8.

16. Ali SM, Lindstrom M. Psychosocial work conditions and leisure time physical activity: a population base study. Scand J Public Health 2006;34:209-16.

17. Bronfenbrenner U. Ecological models of human development. Oxford: Elsevier, 1994:37-43.

18. Fylkesnes K. Determinants of health care utilization-visits and referrals. Scand J Sociol Med 1993;21:40-50.

19. Idler EL, Benyamini Y. Self-rated health and mortality: a review of twenty-seven community studies. J Health Sociol Behav 1997;38:21-37.

20. Lundberg O, Manderbacka K. Assessing reliability of a measure of self-rated health. Scand J Soc Med 1996;24:218-24.

21. Johnson PB, Richter L. The relationship between smoking, drinking, and adolescents' self-perceived health and frequency of hospitalization: analyses from the 1997 National Household Survey on Drug Abuse. J Adolesc Health 2002;30:175-83.

22. Koivusilta L, Arja R, Andres V. Health behaviours and health in adolescence as predictors of educational level in adulthood: a follow-up study from Finland. Soc Sci Med 2003;57:577-93.

23. Pastor $Y$, Balaguer I, Pons D, et al. Testing direct and indirect effects of sports participation on perceived health in Spanish adolescents between 15 and 18 years of age. J Adolesc 2003;26:717-30.

24. Tobi H, Meijer WM, Tuinstra J, et al. Socio-economic differences in prescription and OTC drug use in Dutch adolescents. Pharm World Sci 2003;25:203-6.

25. Morrow V. Conceptualising social capital in relation to the well-being of children and young people: a critical review. Sociol Rev 1999;44:744-65.

26. Duke NN, Skay CL, Pettingell SL, et al. From adolescent connections to social capital: predictors of civic engagement in young adulthood. J Adolesc Health 2009;44:161-8.

27. Craig CL, Marshall AL, Sjöström M, et al. International physical activity questionnaire: 12 -country reliability and validity. Med Sci Sports Exerc 2003;35:1381-95.

28. Subramanian SV, Kim DJ, Kawachi I. Social trust and self-rated health in us communities: a multilevel analysis. J Urban Health 2002;79(Suppl 1):S21-34.

29. Wang Z, Byrne NM, Kenardy JA, et al. Influences of ethnicity and socioeconomic status on the body dissatisfaction and eating behaviour of Australian children and adolescents. Eat Behav 2005;6:23-33.

30. Kessler RC, Barker PR, Colpe LJ, et al. Screening for serious mental illness in the general population. Arch Gen Psychiatry 2003;60:184-9.

31. Green JG, Gruber MJ, Sampson NA, et al. Improving the K6 short scale to predict serious emotional disturbance in adolescents in the USA. Int J Methods Psychiatr Res 2010;19:23-35. 
32. Drukker M, Kaplan C, Feron F. Children's health related quality of life, neighborhood socio-economic deprivation and social capital. A contextual analyses. Soc Sci Med 2003;57:825-41.

33. Ilisin V, Potocnik D. A sociological portrait of contemporary Croatian youth. Ser Hist Sociol 2010;20:41-56.

34. Morrow V. Young people's explanations and experiences of social exclusion: retrieving bourdieu's concept of social capital. Int J Sociol Soc Policy 2001;21:37-63.

35. Morgan A, Haglund BJ. Social capital does matter for adolescent health: evidence from the English HBSC study. Health Promot Int 2009;24:363-72.

36. Kennedy BP, Kawachi I, Brainerd E. The role of social capital in the Russian mortality crisis. World Dev 1998;26:2029-43.

37. Due P, Lynch J, Holstein B, et al. Socioeconomic health inequalities among a nationally representative sample of Danish adolescents: the role of different types of social relations. J Epidemiol Community Health 2003;57:692-8.

38. Newman BM, Lohman BJ, Newman PR. Peer group membership and a sense of belonging: their relationship to adolescent behavior problems. Adolesc 2007;42:241-63.

39. Galambos N. Gender and gender-role development in adolescence. In: Lemer R, Steinberg L eds. The handbook of adolescent psychology. New York: Wiley, 2004:233-62.

40. Binbay T, Drukker $\mathrm{K}$, Alptekin $\mathrm{H}$, et al. Evidence that the wider social environment moderates the association between familial liability and psychosis spectrum outcome. Psychol Med 2012;42:2499-510.

41. Onyx L, Bullen P. Measuring social capital in five communities. J Appl Behav Sci 2000;36:23-42. 